\title{
Excellence in Higher
}

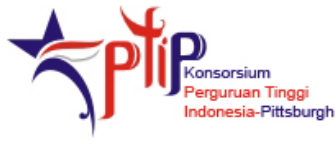

\section{Private Regional Universities as Alternatives to World Class Universities: Achievable Goals for Developing Nations}

\author{
Keith J. Roberts, \\ ${ }^{a}$ University of Pittsburgh, USA
}

\begin{abstract}
A predominant discussion in Asian higher education is the identification and value of world class universities. The pressure to develop world class universities is coming from two sectors. First, the governments themselves see a world class university as a critical prerequisite to moving innovation into the economy and thereby moving the economy ahead and also as a source of status and prestige for the country. Second, parents who are keenly aware of the best universities in the world apply pressure to have equally prestigious universities in their native countries. Although world class universities move the frontiers of knowledge ahead, and clearly help their nation by providing a source of scientists and educated professionals via their graduate schools, many students, especially undergraduates, may be better served by regional universities with emphasis on pedagogy at the undergraduate level. The purpose of this article is to propose that regional private universities provide an alternative, not a replacement, to large research universities as a meaningful investment for both the regional economy and the student.
\end{abstract}

Abstrak

Pembahasan utama di kalangan pendidikan tinggi di Asia dewasa ini adalah identifikasi dan penghargaan atas universitas kelas dunia. Tuntutan akan pengembangan universitas kelas dunia berasal dari dua sektor. Pertama, pemerintah sendiri melihat posisi universitas kelas dunia sebagai syarat utama untuk mewujudkan inovasi yang berorientasi ekonomi, sehingga membantu laju ekonomi, dan juga sebagai parameter status serta prestise bangsa. Kedua, para orang tua yang paham dengan perkembangan universitas terbaik di dunia, sangat mengharapkan adanya universitas di dalam negeri yang tidak kalah maju dan bergengsi. Diakui, universitas kelas dunia lebih maju dalam hal keilmuan, dan jelas berkontribusi menghasilkan sederet ilmuwan dan professional terpelajar lulusan dari program pasca sarjana mereka. Namun, para mahasiswa, terutama strata-1, dapat ditangani dengan lebih baik oleh universitas lokal dengan penekanan pada unsur-unsur pedagogis. Tujuan makalah ini adalah untuk menegaskan bahwa universitas swasta lokal bukannya berperan sebagai pengganti universitas besar yang berorientasi riset, melainkan berfungsi sebagai alternatif investasi pendidikan yang manfaatnya signifikan bagi mahasiswa dan perkembangan ekonomi daerah.

Key Words: World Class Universities, Regional Universities, Private Universities, Internships, Service Learning

\section{Introduction}

The predominant discussion in higher education, especially among Asian nations, is the identification and value of world class universities. China, in particular, has made the identification of several universities to become world class a high priority. Other, smaller, emerging nations have also identified the development of

*Corresponding author. Address: Senior Research Fellow, Institute for International Studies in Education, University of Pittsburgh, 5662 Grove Terrace, Greendale, Wisconsin 531291553, USA. Email: robertsk42@gmail.com. world class universities a high priority. For example, Vietnam is currently identifying the details and structure of a "New Model" university in Hanoi to eventually become a world class university.

Asia's "City-States" of Singapore and Hong Kong have made great strides in improving the world ranking of their universities. The pressure to develop world class universities is currently coming from two sectors. First, the governments themselves see a world class university not only as a critical prerequisite to moving innovation into the economy and thereby moving the economy ahead, but, it also sees a world class university as a source of status and prestige for the country. Second, parents who are keenly aware of the best colleges and universities in the world apply 
pressure to have equally prestigious universities in their native countries. Chinese parents who send their children to the United States want them to study at the top 20, or top 50, or top 100 universities.

Although world class universities move the frontiers of knowledge ahead, and clearly help the nation they are in along with providing a source of scientists and educated professionals via their graduate schools, many students, especially undergraduates, may be better served by regional universities with emphasis on pedagogy at the undergraduate level.

During the World University Presidents' Summit in Bangkok in 2007 a recurring theme of higher education was the need to prepare students not only to work in an economy, but also to live in a society. Although few US universities were represented at the conference, current trends in undergraduate education in the United States support these two objectives. This is evident in the regional comprehensive, both public and private, universities. The purpose of this article is to propose that regional private universities provide an alternative to, not a replacement for, large research universities as a meaningful investment for both the regional economy and the student.

\section{Higher Education and World Class Universities}

Higher education in the US is certainly diverse and is delivered at many levels from technical and community colleges to comprehensive universities. The majority of these institutions have clearly stated missions that place them in specific roles relative to their communities, their potential students, the workforce and society. This diversity of institutions is part of what makes the US higher education system strong. But, the sector of higher education that carries status across borders is the world class research university. This is evident in the various lists attempting to define the best universities in the world. The practice of distinguishing between further and higher education in the UK is additional evidence of this. In this article, higher education will mean the various senior institutions that award bachelor's degrees and above. I will specifically discuss world class universities and regional universities.

The university as we know it today evolved from the institutions of medieval Europe and several of the Great Universities of the world are the traditional universities of Europe. But, over the years the United States has become the envy of the rest of the world in the quality of graduate education being offered in its many prestigious world class research universities. According to the Shanghai Jiao Tong Institute of Higher Education (2011), 17 of the 20 best universities in the world are in the United States. Each year thousands of students come to the United States to study both as graduates and undergraduates.

These international students who study in the US are influenced not only by what happens in the university, but also by what occurs outside the university as they interface with American culture. They begin to understand democracy, capitalism, freedom, and religion from the point of view of a college student. Their "slice of America" is as varied as their university, its community and their major. But, in some way, each will become Americanized.

At the same time, universities in emerging nations are looking to US higher education as a model for their universities. Much of the professional discussion regarding US higher education has to do with its "fitness for purpose" for the American people. But what US higher education becomes impacts the world in several ways. First, international students studying in the United States will become somewhat Americanized and, if they return home, be influenced by the ethics and morality evident in US higher education as they reintegrate into their home countries. Second, as many of these countries look to the United States as a model of higher education they will adapt our system, along with its flaws, to their emerging higher education needs. This is becoming evident in the increased number of international partnerships with universities in the United States.

This article will briefly review the evolution of higher education in the United States, discuss current concerns in US higher education, and relate them to higher education in the emerging nations. I will propose that the strength of US higher education is not only in its world class research universities but also in its wide diversity of institutions. I also propose that the regional comprehensive university is not only an effective university in the United States for educating international students, but also a worthy, cost effective model as a university in developing nations.

\section{World Universities}

The university, as we know it, has grown out of a Western tradition and has been exported throughout the world as one of the artifacts of colonialism. Although the details of higher (tertiary) education are different from place to place, the general concept and purposes are similar because of this colonial activity. Two significant results are currently evident: first, the influence of the British System in the Commonwealth nations; and second, the predominance of English as the medium of higher education. There are currently tensions within international higher education between the evolving Bologna Accord degree programs of Europe along with the British Commonwealth nations, both of which 
include a three-year bachelor's degree, and the US model of a four-year bachelor's degree.

The Shanghai Jiao Tong Institute of Higher Education (SJTIHE) accelerated the discussion regarding world class universities when it initiated its first ranking in 2003. Since then, discussion regarding the development of world class universities has increased and has become especially intense in China and Southeast Asia. The most recent ranking of the top 500 universities in the world was completed in 2011. The top 20 universities, their countries and the language of instruction are listed in Table 1.

Table 1. Top 20 Universities in the World

\begin{tabular}{lcc}
\hline University & Country & Language \\
\hline Harvard University & USA & English \\
Stanford University & USA & English \\
Massachusetts Institute of Technology & USA & English \\
University of California, Berkeley & USA & English \\
University of Cambridge & UK & English \\
California Institute of Technology & USA & English \\
Princeton University & USA & English \\
Columbia University & USA & English \\
University of Chicago & USA & English \\
University of Oxford & UK & English \\
Yale University & USA & English \\
University of California, Los Angeles & USA & English \\
Cornell University & USA & English \\
University of Pennsylvania & USA & English \\
University of California, an Diego & USA & English \\
University of Washington & USA & English \\
University of California, San Francisco & USA & English \\
The Johns Hopkins University & USA & English \\
University of Wisconsin-Madison & USA & English \\
University of London & UK & English \\
\hline
\end{tabular}

Source: SJTIHE (2011).

All 20 of these universities have English as the language of instruction. Therefore, the educated elite of the world will have a high probability of having been taught in English. These universities are ranked according to criteria that are defined to evaluate research quality and productivity. These are truly the "Best Research Universities" in the world. These are the universities that the top student scholars in the world seek out.

Seventeen of these top research universities are in the United States. Charles M. Vest (2005), the President of the Massachusetts Institute of Technology, outlines the factors he believes contribute to the "excellence and competitive success" of higher education in the US:
- The diversity of institutions-from small liberal arts colleges to large public and private universities-allows students to select the school that best matches their needs.

- New assistant professors have freedom to choose what they teach as well as research.

- Our research universities weave together teaching and research in ways that bring freshness, intensity and renewal to both activities.

- We welcome students, scholars and faculty from abroad. Their intellectual and cultural richness help define our institutions.

- Support of frontier research in our universities has long been an important responsibility of the federal government, which awards grants to researchers on the basis of their merit in a competitive marketplace of ideas.

- A tradition of philanthropy, fostered by US tax law, encourages alumni and others to support our colleges and universities. Scholarship funds they provide allow talented students from families of modest means to attend even the most costly schools.

- Open competition for faculty and students drive excellence.

Two of the above factors are important to our discussion. First, the diversity of institutions, even though the many non-research colleges and universities in the United States are not listed as the "Best in the World," these institutions often supply the graduate students who perform well in the ranked research universities. Many of these are regional comprehensive universities. It is important for a developing economy also to develop the equivalent of these regional universities to feed the graduate programs of the research universities. Second, the inclusion of students, scholars and faculty from abroad; these international participants provide an intellectual richness to US institutions. International partnerships with US universities will bring that diversity to the international campus.

\section{The Private University in the United States}

The early US colleges that were established in the colonial era were sponsored by various religious groups and were modeled after the British universities of Oxford and Cambridge. The idea of a residential college where students and scholars live and study together remains in the American psyche. The sense of shared mission and community has remained a theme within higher education in the US from the colonial times until now. The remaining colonial colleges, those founded before 1781, still maintain prestige, in part because of this mystique of community. These universities: Harvard University, The College of William and Mary, Yale University, Princeton University, Columbia University, Brown University, Dartmouth College, Rutgers 
University, and the University of Pennsylvania all maintain their colonial architecture as a physical reminder of their colonial heritage. These universities were all private universities, but the College of William and Mary and Rutgers University are now public.

Public research universities in the United States evolved from the "land grant" legislation of the eighteenth and nineteenth century. The provisions of the Northwest Ordinance (1787) and the Morrill Act (1862) set aside land for universities "to establish collegiate programs in such 'useful arts' as agriculture, mechanics, mining, and military instruction" (Thelin 2004, 76). These higher education institutions, which started as regional universities, would eventually become the flagship research universities of each state. The lesson for developing nations may be to model new universities after the "original" land grant universities and have them evolve into the equivalent of the "modern" land grant universities.

Another source of public higher education was the normal school. In the nineteenth century teacher education in the United States was supported by the development of normal schools that provided licenses for teachers. These schools eventually became teachers' colleges that awarded bachelor's degrees, then state colleges and eventually regional state universities that award bachelor's degrees, master's degrees in applied areas and a few doctorates. The majority of America's regional public universities grew out of these normal schools.

At the same time small denominational colleges were springing up throughout the East, South and Midwest. These flourished at different rates. Some closed, some merged and many continue into the twenty-first century as prominent private, religiously affiliated universities.

Together, these trends evolved into a diverse selection of higher education institutions in the US that allow for a variety of choices so students can select the colleges or universities that best meet their needs. There are currently approximately 3,400 higher education institutions in the United States, of which 2,200 award bachelor's degrees or above. These institutions are independent from each other and could not be considered a "system" of higher education.

In 1900, the presidents of fourteen of the most prestigious universities in the US met and formed the Association of American Universities. The charter members were: Harvard University; Johns Hopkins University; Columbia University; University of Chicago; University of California; Clark University; Cornell University; Catholic University; University of Michigan; Leland Stanford, Jr. University (later to become Stanford University); University of Wisconsin; University of Pennsylvania; Princeton University; and Yale University. All but Michigan and
Wisconsin were private. A few years later Edwin Slosson, editor of The Independent, published Great American Universities, a book which contained 12 of the original 14 universities. Slosson replaced Clark University and Catholic University with the University of Illinois and the University of Minnesota, both public institutions (Thelin 2004, 76).

The most visible and longest running ranking of colleges and universities in the US has been conducted by US News \& World Report. Although it is a proprietary, "reputational" ranking with a methodology less rigorous than the Shanghi Jiao Tong rankings, it is used here because it is the only ranking also to include all of the smaller, less visible regional universities. In the most recent ranking of the 248 national universities, 13 of these 14 are listed in the top 50 national universities by U.S. News \& World Report, whereas all 14 are in the top 50 research universities in the world according to the Jiao Tong rankings. The Edwin Slosson 14 are listed below with their 2011 U.S. News \& World Report and Shanghai Jiao Tong rankings:

Table 2. Slosson 14 Ranked by U.S. News \& World Report and SJTIHE

\begin{tabular}{|c|c|c|c|}
\hline University & $\begin{array}{c}\text { Institution } \\
\text { Type }\end{array}$ & $\begin{array}{l}\text { U.S. News \& } \\
\text { World Report }\end{array}$ & $\begin{array}{l}\text { Shanghai } \\
\text { Jiao Tong }\end{array}$ \\
\hline Harvard University & Private & 1 & 1 \\
\hline Princeton University & Private & 2 & 7 \\
\hline Yale University & Private & 3 & 11 \\
\hline Columbia University & Private & 4 & 8 \\
\hline Stanford University & Private & 5 & 2 \\
\hline $\begin{array}{l}\text { University of Pennsyl- } \\
\text { vania }\end{array}$ & Private & 6 & 14 \\
\hline University of Chicago & Private & 9 & 9 \\
\hline Johns Hopkins University & Private & 13 & 18 \\
\hline Cornell University & Private & 15 & 13 \\
\hline $\begin{array}{l}\text { University of California, } \\
\text { Berkeley }\end{array}$ & Public & 22 & 4 \\
\hline University of Michigan & Public & 29 & 22 \\
\hline $\begin{array}{l}\text { University of Wisconsin- } \\
\text { Madison }\end{array}$ & Public & 45 & 19 \\
\hline $\begin{array}{l}\text { University of Illinois- } \\
\text { Urbana/Champaign }\end{array}$ & Public & 47 & 25 \\
\hline $\begin{array}{l}\text { University of Minnesota- } \\
\text { Twin Cities }\end{array}$ & Public & 64 & 28 \\
\hline
\end{tabular}

Sources: U.S. News \& World Report (2010) and SJTIHE (2011).

The nine private universities of the original 14 are still ranked in the top 15 over 100 years later. Four of the five public universities in the original 14 are ranked in the top 50 with only the University of Minnesota falling out of the top 50, being ranked at 64. This illustrates how enduring reputation is in US institutions of higher education. It would make sense that the private universities would rise to the top because they are well endowed and maintain market appeal through high tuition. The public 
universities on the other hand, although well funded, have less per student funding available. In addition, the public universities have been under pressure over the last 50 years to become accessible to a wider spectrum of students. What is interesting is the relative higher ranking of public universities among world universities. The five public universities in the Slosson list are all ranked higher in the World than they are in the US. This is clearly a result of the well funded research programs in these Land Grant institutions and the fact that the world rankings weigh research productivity highly.

In the meantime 12 religious universities who keep their religious affiliation in their mission statements were ranked in the top 100 national (doctoral) universities by U.S. News \& World Report for 2011 (see Table 3).

Table 3. Top Religious Doctoral Universities in US in 2011

\begin{tabular}{lc}
\hline University & US Ranking \\
\hline University of Notre Dame & 19 \\
Georgetown University & 21 \\
Boston College & 31 \\
Yeshiva University & 50 \\
Pepperdine University & 53 \\
Fordham University & 56 \\
Southern Methodist University & 56 \\
Brigham Young University-Provo & 75 \\
Marquette University & 75 \\
Baylor University & 79 \\
St. Louis University & 86 \\
Texas Christian & 99 \\
\hline
\end{tabular}

Source: U.S. News \& World Report (2010).

\section{Regional Universities in the United States}

The backbone of higher education in the US are the public and private regional universities that educate the majority of middle class students. These regional universities provide a liberal arts core (often referred to as General Education) along with a mixture of traditional and career oriented majors. Regional universities often offer master's degrees in specific careers that reflect the needs of the immediate regional job market. Doctorates are seldom offered, but when they are offered it is in professional areas such as education.

As with the other sectors of higher education in the United States, regional universities are currently concerned with two important trends in higher education in the US - service learning and internships. These two trends respond to the challenge of higher education as identified at the World Universities Presidents Summit: work in an economy (internships) and live in a society (service learning). In addition to these two initiatives, regional universities are active in undergraduate research.
Regional universities are on the forefront of preparing students to work in an economy. Private institutions, with higher tuition and fees, are especially concerned about the suitability of their graduates for careers. Nearly all universities in the United States have an office of Internships and Career Services. Butler University, ranked second in the Midwest by U.S. News \& World Report for 2011, is typical of effective private regional universities. Butler University references the Indiana INTERNnet (2010) guidelines for maximizing internships; the guidelines provide a brief explanation of experiential learning as follows:

Experiential learning is the process of translating experiences into knowledge. It is learning by doing, and applying this learning into a meaningful form to translate into knowledge for the student.

This kind of learning takes the form of internships, co-ops, practica, field experience and apprenticeships. The student is immersed into a real world situation under the guide of an experienced professional and begins to learn how to perform various tasks within that profession. In order to be meaningful, the experiential education needs to encompass the following steps:

- being exposed to the experience;

- reflecting upon the experience and examining the process;

- securing support, in the form of time, resources and opportunities to continue changing; and

- transferring or changing the experience into knowledge that is applicable to real life in the way it promotes and implements internships.

Just as internships and other forms of experiential learning prepare students to work in an economy, service learning prepares students to live in a society. Below is an example of service learning provided by the National Service-Learning Clearinghouse (2011):

If school students collect trash out of an urban streambed, they are providing a valued service to the community as volunteers. If school students collect trash from an urban streambed, analyze their findings to determine the possible sources of pollution, and share the results with residents of the neighborhood, they are engaging in service-learning.

In the service-learning example, in addition to providing an important service to the community, students are learning 
about water quality and laboratory analysis, developing an understanding of pollution issues, and practicing communications skills. They may also reflect on their personal and career interests in science, the environment, public policy or other related areas. Both the students and the community have been involved in a transformative experience.

The number one ranked regional university in the Midwest, Creighton University in Omaha, Nebraska, provides an excellent example of how service learning aids the students and the region. Similar to other institutions, Creighton University draws from Eyler and Giles' (1999) definition of service learning as:

a form of experiential education where learning occurs through a cycle of action and reflection as students work with others through a process of applying what they are learning to community problems and, at the same time, reflecting upon their experience as they seek to achieve real objectives for the community and deeper understanding and skills for themselves.

In the United States, the President's Higher Education Community Service Honor Roll was established in 2006. The Honor Roll recognizes institutions of higher education that support exemplary student community service and service learning programs, thereby encouraging growth in the number of college students engaged in community service and service learning each year. Creighton University (2011), a private regional university, was named to the Honor Roll for four consecutive years.

The number one ranked regional university in the North, Villanova University (2011a), addresses service learning through a three credit course described as follows:

What is Service Learning? Service Learning courses are threecredit courses which connect course objectives with opportunities to meet the needs of people in underserved communities or work with agencies which advocate for the poor and or care for the environment. Integration of theoretical knowledge and experiential learning in the community provides a context for critical and constructive thinking and action that promotes the common good.

According to those involved with service learning at Villanova University (2011a),

the community experience also provides a context for meaningful reflection which is an essential component of service learning. Our students and faculty will learn with people who face the challenges of poverty and marginalization and those who work to protect our environment. We will transform one another through these relationships.

A Service Learning course is a concrete expression of the College of Liberal Arts and Sciences' commitment to values inherent in Catholic Social Teaching. The College will continue to build partnerships with agencies and schools who serve the poor and our environment so as to live out our mission to "prepare students to regard themselves as citizens living in a democratic society, as belonging to a world community, replete with communal responsibilities."

As a result of this kind of commitment,

Villanova University has been recognized by the National Hispanic Institute (NHI) as the organization's 2010 "University of the Year." The University was honored for its "unparalleled commitment to developing driven, community-conscious leaders." (Villanova 2011b)

In addition to the creative initiatives in internships and service learning, regional universities are also active in providing undergraduate research opportunities. Because regional universities are less likely to offer extensive graduate research programs, the faculty are more likely to mentor undergraduates in research. This prepares the undergraduate for success in graduate programs. One interesting example is Providence College, the second ranked regional university in the North region. Providence College (2011) is typical of regional universities in that it has a standing committee on undergraduate research. The committee is responsible for advancing undergraduate research by:

- leading the College's effort to achieve [the] strategic goal,

- consulting with the Center for Teaching Excellence, the Committee for the Enhancement of Learning and the Student Engagement Advisory Committee to ensure greater connections between undergraduate research and student engagement in learning, and

- engaging in outreach with the campus community by advocating the benefits of undergraduate research at the College.

Another approach to undergraduate research is used at Trinity University in San Antonio, Texas, the number one regional university in the Western United States. Trinity University (2011) provides opportunities during the summer as described at their website: 
Undergraduate research is central to the goals and priorities of the academic program at Trinity University. During the 10week Summer Program, students work on research projects full-time under the close mentorship of Trinity faculty. These research experiences allow students to develop a more complete picture of careers in research and academia.

It is these kinds of activities, internships, service learning, and undergraduate research that prepare the students to enter the community, enter the workforce, and enter graduate and professional education.

Each year U.S. News \& World Report provides a ranking of US universities. Although this is a proprietary "reputational" ranking, it is the only one that includes these regional universities and is therefore used to identify universities of interest in each region (see Tables 4-7).

Table 4. Top Ten Universities in Midwest Region in 2011

\begin{tabular}{llc}
\hline University & Institution Type & $\begin{array}{c}\text { Year of } \\
\text { Founding }\end{array}$ \\
\hline Creighton University & Private/Catholic/Jesuit & 1878 \\
Butler University & Private & 1855 \\
Drake University & Private & 1881 \\
Xavier University & Private/Catholic/Jesuit & 1831 \\
& (tied for 3) & \\
Valpariso University & Private/Lutheran & 1859 \\
Bradley University & Private & 1897 \\
John Carroll University & Private/Catholic/Jesuit & 1886 \\
Truman State University & Public & 1867 \\
Hamline University & Private/Methodist & 1854 \\
University of Evansville & Private/Methodist & 1854 \\
\hline Source: $U S$ Sews \& World Report & (2010). &
\end{tabular}

Source: U.S. News \& World Report (2010).

Table 5. Top Ten Universities in North Region in 2011

\begin{tabular}{llc}
\hline University & Institution Type & $\begin{array}{c}\text { Year of } \\
\text { Founding }\end{array}$ \\
\hline Villanova University & Private/Catholic & 1842 \\
Providence College & Private/Catholic & 1917 \\
Loyoa University of Maryland & Private/Catholic/Jesuit & 1852 \\
Bentley University & Private (tied for 3) & 1917 \\
College of New Jersey & Public (tied for 3) & 1855 \\
Fairfield University & Private/Catholic/Jesuit & 1942 \\
& (tied for 7) & \\
Ithica College & Private & 1892 \\
Rochester Institute of Tech. & Private & 1829 \\
Quinnipiac University & Private & 1929 \\
Marist College & Private & 1929 \\
University of Scranton & Private/Catholic/Jesuit & 1888 \\
& (tied for 10) & \\
\hline Source: US. News \& World Report & (2010) &
\end{tabular}

The top ten regional universities in the United States, which were identified by U.S. News \& World Report for 2011 in each of four regions, are listed in Tables 4-7, with the year of founding and the nature of control (Private/Public) also provided. In the Midwest region, nine of ten universities are private and six are religiously affiliated. All are over 100 years old; the average number of years these institutions have been in operation is 144. In the North region ten of 11 universities are private and five are religiously affiliated. Eight are over 100 years old. In the South region, seven of ten universities are private and four are religiously affiliated. Eight are over 100 years old. In the West region ten of the 11 universities are private and seven are religiously affiliated. Ten are over 100 years old and one is 99 years old.

Table 6. Top Ten Universities in South Region in 2011

\begin{tabular}{llc}
\hline University & Institution Type & $\begin{array}{c}\text { Year of } \\
\text { Founding }\end{array}$ \\
\hline Rollins College & Private & 1885 \\
Elon University & $\begin{array}{l}\text { Private/United } \\
\text { Church of Christ }\end{array}$ & 1889 \\
James Madison University & Public & 1908 \\
Stetson University & Private (tied for 3) & 1883 \\
Belmont University & Private/Christian & 1890 \\
& Ecumenical & \\
The Citadel & Public & 1842 \\
Loyola University of New & Private/Catholic/ & 1912 \\
$\quad$ Orleans & Jesuit & 1833 \\
Mercer University & Private/Baptist & 1899 \\
Appalachian State University & Public & 1926 \\
Embry-Riddle Aeronautical & Private & \\
$\quad$ University & & \\
\hline Source: U.S. News \& World Report & (2010).
\end{tabular}

Table 7. Top Ten Universities in West Region in 2011

\begin{tabular}{llc}
\hline University & Institution Type & $\begin{array}{c}\text { Year of } \\
\text { Founding }\end{array}$ \\
\hline Trinity University & Private/Presbyterian & 1869 \\
Santa Clara University & Private/Catholic & 1851 \\
Loyola Marymount University & Private/Catholic & 1911 \\
Gonzaga University & Private/Catholic & 1887 \\
Mills College & Private (tied for 4) & 1852 \\
California Polytechnic State & Public & 1901 \\
$\quad$ University, San Luis Obispo & Private/Catholic/Jesuit & 1891 \\
Seattle University & (tied for 6) & 1861 \\
Chapman University & Private/Disciples of & \\
& Christ & 1901 \\
University of Portland & Private/Catholic & 1907 \\
University of Redlands & Private (tied for 9) & 1890 \\
Whitworth University & Private (tied for 9) & \\
\hline Source: U.S. News \& World Report & (2010).
\end{tabular}


The strength of higher education in the United States is that it allows the diversity of institutions, so when institutions evolve away from their original mission others will move into the mission if there is a market. Clearly, there is a market for good regional universities.

\section{Conclusion}

Although the predominant discussion in higher education is the identification and value of world class universities, and emerging nations have identified the development of world class universities as a high priority, it is important to consider good regional universities as a valuable 'first step" for emerging nations.

Even though world class universities move the frontiers of knowledge ahead and help the nation they are in, many students, especially undergraduates, may be better served by regional universities with emphasis on pedagogy at the undergraduate level.

During the World University Presidents' Summit in Bangkok in 2007, a recurring theme of higher education was the need to prepare students not only to work in an economy, but also to live in a society. This is currently being addressed successfully in regional universities in the United States via service learning, internships and undergraduate research. A review of top ranked regional universities in the United States shows that even though there are many good public regional universities, the majority of the highly ranked regional universities are private. I therefore propose that the development of private regional universities be considered as an alternative, not a replacement, to large research universities as a meaningful investment for both the regional economy and the student.

\section{References}

Creighton University. 2011. Service-Learning. Omaha, NE: Creighton University. Available online at: http://creighton.edu.

Eyler, Janet, and Dwight E. Giles. 1999. Where's the Learning in Service-Learning? San Francisco: Jossey-Bass.

Indiana INTERNnet. 2010. Indianapolis, IN. Available online at: http://indianaintern.net.

National Service-Learning Clearinghouse. 2011. What is ServiceLearning? Scotts Valley, CA: ETR Associates. Available online at: http://servicelearning.org.

Providence College. 2011. Undergraduate Research Committee. Providence, RI: Providence College. Available online at: http://providence.edu.
Shanghai Jiao Tong Institute of Higher Education [SJTIHE]. 2011. Academic Ranking of World Universities. Shanghai: SJTIHE. Available online at: http://shanghairanking.com.

Thelin, John R. 2004. A History of American Higher Education. Baltimore, MD: The John Hopkins University Press.

Trinity University. 2011. Undergraduate Research at Trinity. San Antonio, TX: Trinity University. Available online at: http://trinity.edu.

U.S. News \& World Report. 2010. Regional University Rankings. Washington, DC: U.S. News and World Report. Available online at: http://www.usnews.com.

Vest, Charles M. 2005. "World Class Universities: American Lessons." International Higher Education 38 (Winter): 6-7. Available online at: http://www.bc.edu/cihe.

Villanova University. 2011a. Office of Service Learning. Villanova, PA: Villanova University. Available online at: http://www.villanova.edu.

Villanova University. 2011b. Villanova Named 2010 "University of the Year" by National Hispanic Institute (NHI). Villanova, PA: Villanova University. Available online at: http://www.villanova.edu. 